\title{
Evaluation of lime mortars for the repair of historic buildings
}

\author{
M. Abdel-Mooty, S. Khedr \& T. Mahfouz \\ Department of Construction and Architectural Engineering, \\ The American University in Cairo, Egypt
}

\begin{abstract}
The repair and rehabilitation of old historic structures involve a complex interaction of existing and new elements. Several difficulties are encountered by researchers and design engineers in this effort. Engineering judgment, perception, and experience have been used in many cases due to the lack of technical guidelines in a worldwide context. Consequently, a research studying different restoration mortars became a necessity. To fulfil this need, this research attempts to evaluate the performance of some of the currently used mortars and develop new ones. Several tests were conducted on lime based mortars using white cement, gypsum, lignin sulfonate, and silica fume that are used to enhance the mortars' performance. These mortars were tested for compressive, tensile, and shear strengths at 7,28, and 56 days from mixing. As a durability test, weight loss of mortar cubes subjected to wetting and drying cycles was measured. In addition, models of wall prisms were built using these mortars and tested under in-plan compressive loads to study the composite structural behaviour and bonding of stones and mortars. Based on the results of these tests, it was found that lime based mortars prepared using silica fume yielded the highest compressive, tensile, and shear strength. On the other hand, lime based mortars prepared using lignin sulfonate have attained the best results concerning wetting and drying cycles and the highest load capacity for the model wall, which resembled structural behaviour and bonding.
\end{abstract}

Keywords: historic buildings, lime mortar, natural stone wall, restoration. 


\section{Introduction}

The restoration of monuments and historic buildings is a wide topic that comprises different attributes, such as integrity, constituents, and durability of the structures. This research focuses on one of the key subjects in such a realm, which is lime mortars used in stone masonry building restoration. Many of the historic buildings were constructed using limestone, lime mortar or both.

The common types used in many of the old buildings are hydraulic limes. Lime was used with filler in the form of aggregates to make mortar. Aggregates were commonly rounded or angular sand and may contain small portions of variety of material such as stone dust, chalk, seashell and ash. The proportion of binder to filler was normally $1: 3$ [1]. The performance of the mortar is affected by the size, the condition and the quantity of the filler.

Restoration of ancient buildings usually involves restoring the integrity of the walls by restoring the strength of the mortar. Protection of historic works of art, architectural look, durability, and strength limits the choices of mortar used in restoration. The use of any binding material that would damage the painting and limestone façade, because of the chemical reaction developed during the process of hardening, is not permitted. Portland cement, for example, is known for its aggressive nature when used with limestone. They react chemically in the presence of water (even in small amounts) to produce simpler materials while losing their main characteristics in terms of compressive strength and binding ability. Therefore, Portland cement is not allowed as a binding material in mortars and grout. Lime, on the other hand, while it is chemically compatible with limestone, it has relatively low strength and durability. Lime is preferred over cement for its compatibility with the natural stones masonry and mortars of the old buildings. Furthermore, lime mortar allows moisture to pass through it in both directions, so water is not trapped inside and hence it may not have the chance to react with the building components [2-7].

Different restoration techniques are applied based on the cause of damage. Each would require a different type of mortar in terms of bonding strength, workability and durability. Consequently, a study that evaluates the available lime mortar mixes and newly developed lime based ones is a necessity.

This work focuses on evaluating and improving the performance of limebased mortar in terms of strength and durability. Different binding substances were added to the lime binder in the mortar mix with different proportions. The binder used in this research are gypsum, white cement, silica fume and lignin sulfonate. The performance of the developed mortar mixes are evaluated in small wall prisms made of limestone blocks and lime mortar joints under in-plane compression.

Because of its extreme fineness, large surface area, and high silica content, silica fume is a highly effective pozzolanic material that a very strong ground for bonding. Lime particles unite with the silica and form a silicate of lime capable of resisting the action of water. In addition, aluminium, ferric, magnesium present in the silica fume reacts with lime in the presence of water resulting in 
the presence of more complex and denser molecules that enhances the strength and forces of attraction between the particles [8].

Lignin is produced as a co-product of the paper industry. It is separated from trees by chemical pulping process. Lignin sulfunate (also called lignosulfunates and sulfide lignins) are products of sulfite pulping. Physical and chemical properties of this material differ depending on the extraction technology used [9]. When lignin is added to lime mortars it complexes salt and metal ions like magnesium to allow for the good performance of the mortar. It also covers the sand crystals and the compound crystals to preserve them. However, lignins are very complex natural polymers with many random couplings; the exact chemical structure is not fully known [10].

Table 1: $\quad$ Mix proportions.

\begin{tabular}{|c|c|c|c|c|c|c|c|}
\hline$\stackrel{\infty}{2}$ & $\begin{array}{l}\text { Mix } \\
\text { No. }\end{array}$ & Lime & $\begin{array}{c}\text { White } \\
\text { Cement }\end{array}$ & Gypsum & $\begin{array}{l}\text { Lignin } \\
\text { Sulfunate } \\
\text { (\% of lime) }\end{array}$ & $\begin{array}{l}\text { Silica Fume } \\
\text { ( } \% \text { of lime) }\end{array}$ & Sand \\
\hline \multirow{12}{*}{ 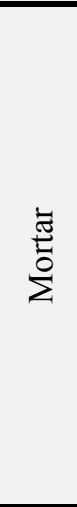 } & 1 & 3 & - & - & - & - & 9 \\
\hline & 2 & 2.5 & 0.5 & - & - & - & 9 \\
\hline & 3 & 2 & 1 & - & - & - & 9 \\
\hline & 4 & 1.5 & 1.5 & - & - & - & 9 \\
\hline & 5 & 2.5 & - & 0.5 & - & - & 9 \\
\hline & 6 & 2 & - & 1 & - & - & 9 \\
\hline & 7 & 1.5 & - & 1.5 & - & - & 9 \\
\hline & 8 & 3 & - & - & 0.6 & - & 9 \\
\hline & 9 & 3 & - & - & 0.8 & - & 9 \\
\hline & 10 & 3 & - & - & - & 5 & 9 \\
\hline & 11 & 3 & - & - & - & 10 & 9 \\
\hline & 12 & 3 & - & - & - & 15 & 9 \\
\hline \multirow{5}{*}{ 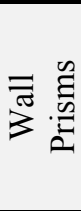 } & 1 & 3 & - & - & - & - & 9 \\
\hline & 3 & 2 & 1 & - & - & - & 9 \\
\hline & 6 & 2 & - & 1 & - & - & 9 \\
\hline & 8 & 3 & - & - & 0.6 & - & 9 \\
\hline & 11 & 3 & - & - & - & 10 & 9 \\
\hline
\end{tabular}

\section{Testing program}

\subsection{Mortar mixes}

The materials used in this investigation are lime (hydrated lime), white cement, gypsum, lignin sulfunate, silica fume, sand (medium to fine), water, and limestone blocks. The mortar mixes proportions are illustrated in Table 1. The ratio by weight of water to cementitious material ratio is 1.3 in all specimens. 
Control mix of lime and sand: The control mix constituents are sand, lime and water with ratio of sand to lime 9:3.

Lime - white cement - sand - water mix: Three mixes were prepared with different ratios of lime and white cement as shown in Table 1.

Lime - gypsum - sand - water mix: Three mixes were prepared with different ratios of lime and gypsum as shown in Table 1.

Lime - lignin sulfunate - sand - water mix: As per the manufacturer recommendations, lignin sulfunate is used in percentages between $0.4 \%$ and $0.8 \%$ of cementitious materials. Based on that, two mixes were prepared with $0.6 \%$ and $0.8 \%$ of lignin sulfunate as shown in Table 1 .

Lime - silica fume - sand - water mix: Silica fume is a highly effective pozzolanic material. Three mixes were prepared with $5 \%, 10 \%$, and $15 \%$ of silica fume as shown in Table 1.

\subsection{Wall prisms}

As for wall prisms, the mid range mix of each mortar group was used to build up wall models that were tested under compression. Table 1 illustrates the mortar mix proportions used for building wall prisms.

\subsection{Testing plan}

Three specimens were tested for each mix of the 12 mixes at each designated age (7, 28, and 56 days). Total of 108 specimens were tested for each property, namely compressive strength, tensile strength, and shear strength. A total of 324 specimens were tested. For the wetting and drying cycles 6 cubes were tested for each mix after 56 days totalling to 72 cubes. Thirty six of which were tested using tap water and the rest were tested using sea water. Three assemblies of walls were tested for each mix totalling to 15 wall prisms. All tests were conducted at the Materials Laboratory of the American University in Cairo.

\section{Experimental results for lime-mortar cube testing}

\subsection{Compressive strength}

Results of average compressive strength of mortar cubes for 7, 28, and 56 days of each mix and the percentage change per mix are illustrated in Table 2. It is clear that when lime mortars are mixed with white cement, gypsum, lignin sulfunate, or silica fumes, they exhibit an increase in compressive strength. Highest results were attained using silica fumes at a percentage of 10 and $15 \%$.

The maximum increase in strength of mortar mixes with white cement was attained in 56 days at a ratio of lime to white cement of 1.5:1.5. This is due to the nature of physical reaction of lime and the chemical reaction of cement that take place in the presence of water. Cements consist of chemical compounds of lime and silica and lime and alumina, which, when mixed with water, combine therewith, forming crystalline substances of high strength, and capable of adhering firmly to clean inert material, such as stone and sand. This hydration process is not finalized in a short period. 
Structural Studies, Repairs and Maintenance of Heritage Architecture XI 213

Table 2: $\quad$ Average compressive strength of mortar cubes.

\begin{tabular}{|c|c|c|c|c|c|}
\hline Mix Name & $\begin{array}{l}\text { Mix } \\
\text { No. }\end{array}$ & Days & $\begin{array}{c}\text { Compressive } \\
\text { Strength } \\
\left(\mathrm{N} / \mathrm{mm}^{2}\right)\end{array}$ & $\begin{array}{c}\% \text { Change } \\
\text { relative to } 7 \\
\text { days per mix }\end{array}$ & $\begin{array}{l}\% \text { Change } \\
\text { relative to } \\
\text { control Mix }\end{array}$ \\
\hline \multirow{3}{*}{ 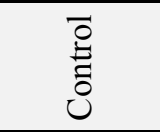 } & \multirow{3}{*}{1} & 7 & 0.47 & & \\
\hline & & 28 & 0.52 & 10.5 & \\
\hline & & 56 & 0.63 & 33.3 & \\
\hline \multirow{9}{*}{ 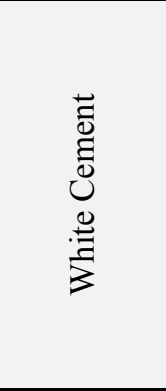 } & \multirow{3}{*}{2} & 7 & 0.63 & & 33.1 \\
\hline & & 28 & 0.87 & 38.3 & 67.5 \\
\hline & & 56 & 0.88 & 40.5 & 40.5 \\
\hline & \multirow{3}{*}{3} & 7 & 0.96 & & 103.2 \\
\hline & & 28 & 1.14 & 18.5 & 118.8 \\
\hline & & 56 & 1.27 & 32.2 & 101.5 \\
\hline & \multirow{3}{*}{4} & 7 & 1.11 & & 136.5 \\
\hline & & 28 & 1.35 & 22.0 & 160.5 \\
\hline & & 56 & 1.76 & 58.2 & 178.8 \\
\hline \multirow{9}{*}{ 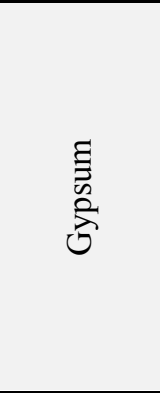 } & \multirow{3}{*}{5} & 7 & 0.51 & & 8.5 \\
\hline & & 28 & 0.54 & 5.7 & 3.6 \\
\hline & & 56 & 0.80 & 56.2 & 26.5 \\
\hline & \multirow{3}{*}{6} & 7 & 0.61 & & 29.7 \\
\hline & & 28 & 0.90 & 46.9 & 72.3 \\
\hline & & 56 & 0.90 & 47.1 & 42.4 \\
\hline & \multirow{3}{*}{7} & 7 & 0.73 & & 55.0 \\
\hline & & 28 & 1.05 & 44.2 & 102.4 \\
\hline & & 56 & 1.15 & 57.1 & 82.0 \\
\hline \multirow{6}{*}{ 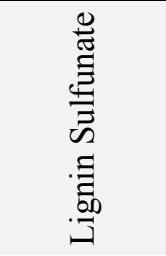 } & \multirow{3}{*}{8} & 7 & 0.50 & & 5.6 \\
\hline & & 28 & 0.78 & 55.4 & 49.4 \\
\hline & & 56 & 1.27 & 153.4 & 101.1 \\
\hline & \multirow{3}{*}{9} & 7 & 0.64 & & 36.5 \\
\hline & & 28 & 0.81 & 26.3 & 55.5 \\
\hline & & 56 & 0.98 & 53.7 & 56.1 \\
\hline \multirow{9}{*}{ 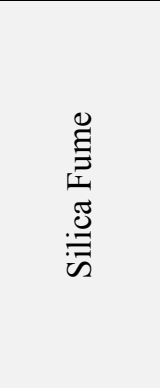 } & \multirow{3}{*}{10} & 7 & 1.15 & & 145.3 \\
\hline & & 28 & 1.71 & 49.1 & 229.7 \\
\hline & & 56 & 2.19 & 90.8 & 248.3 \\
\hline & \multirow{3}{*}{11} & 7 & 1.16 & & 147.0 \\
\hline & & 28 & 1.53 & 31.5 & 193.4 \\
\hline & & 56 & 2.17 & 87.3 & 244.9 \\
\hline & \multirow{3}{*}{12} & 7 & 1.09 & & 130.9 \\
\hline & & 28 & 2.75 & 152.3 & 428.8 \\
\hline & & 56 & 2.63 & 141.4 & 317.6 \\
\hline
\end{tabular}


The three mixes using gypsum show that the rate of gaining strength up to 28 days is generally proportional to the ratio of gypsum to lime added. On the other hand, the total increase after 56 days is nearly constant in all mixes. In other words, the rate of increase in strength after 28 days is inversely proportional to that of the ratio of gypsum to lime added.

It was noticed that mortar with the percentage of $0.6 \%$ of lignin sulfunate exhibits large increase in compressive strength over the 7-day strength of $56.6 \%$ at 28 days and continues up to $155 \%$ at 56 days. With the use of $0.8 \%$ of lignin sulfunate, although 7 days strength was higher than that of $0.6 \%$ mix, mortar cubes exhibit an increase in compressive strength of $26.0 \%$ at 28 days and continues to increase with time up to $53 \%$ at 56 days. It is clear that when lime based mortars are mixed with lignin sulfunate an increase in the compressive strength is achieved. The best performance was accomplished at $0.6 \%$ of lignin sulfunate.

When comparing the results of lime based mortars with silica fumes, it was noticed that mortar compressive strength generally increases. The best performance was accomplished at $15 \%$ of silica fume. Such behaviour is common for silica fume due to its very fine particles that provide a large surface area for reaction and filling in the voids between the particles.

\subsection{Tensile strength}

The control mix exhibits a decrease in tensile strength with time as shown in Table 3. This is mainly due to the fact that, as lime mortars gain compressive strength with time through carbonation in which water dries out, they lose their softness leading to decrease in tensile strength.

The tensile strength of the white cement mixes increases with time during the first 28 days at a rate inversely proportional to the amount of white cement. During the second 28 days, strength gaining is proportional to the amount of white cement with best performance at a lime to white cement ratio of 2.0:1.0.

Lime based mortars with gypsum generally exhibit increase in tensile strength with time of the three mixes. The best performance was attained at a ratio of $\mathrm{L}: \mathrm{G}$ of 1.5:1.5.

Lime based mortars with lignin sulfunate exhibit an increase in the tensile strength. The best performance was accomplished at $0.6 \%$ of lignin sulfunate.

Lime based mortars mixes with silica fumes at 5\%,10\%, and $15 \%$ of used lime exhibit an increase in the tensile strength. The best performance was accomplished at silica fume ratio $15 \%$ of the used lime.

Tensile strength results of Table 3 show that when lime mortars are mixed with white cement, gypsum, lignin sulfunate, or silica fumes they exhibit a loss in tensile strength at 7 days. However, best performance is attained using silica fumes at a percentage of 5 and $15 \%$ at which no loss was attained. At 28 days all mixes exhibit loss of tensile strength except for those prepared using silica fume. Best performance was achieved at $15 \%$ silica fume by weight of cementitious material. Such observations suggest that when tensile strength of the mortar is the critical issue in repair, a mix with $15 \%$ of the weight of cementitious material of silica fume yields the best performance. 
Structural Studies, Repairs and Maintenance of Heritage Architecture XI 215

Table 3: $\quad$ Tensile strength of mortar specimens.

\begin{tabular}{|c|c|c|c|c|c|}
\hline $\begin{array}{c}\text { Mix } \\
\text { Name }\end{array}$ & $\begin{array}{l}\text { Mix } \\
\text { No. }\end{array}$ & Days & $\begin{array}{c}\text { Tensile } \\
\text { strength } \\
\left(\mathrm{N} / \mathrm{mm}^{2}\right)\end{array}$ & $\begin{array}{c}\% \text { Change } \\
\text { compared to } 7 \\
\text { days per Mix }\end{array}$ & $\begin{array}{l}\text { \% Change } \\
\text { Relative to } \\
\text { Control Mix }\end{array}$ \\
\hline \multirow{3}{*}{ 苟 } & \multirow{3}{*}{1} & 7 & 0.32 & & \\
\hline & & 28 & 0.24 & -25.0 & \\
\hline & & 56 & 0.19 & -40.0 & \\
\hline \multirow{9}{*}{ 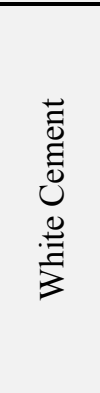 } & \multirow{3}{*}{2} & 7 & 0.16 & & -50.0 \\
\hline & & 28 & 0.20 & 23.3 & -17.8 \\
\hline & & 56 & 0.19 & 20.0 & 1.1 \\
\hline & \multirow{3}{*}{3} & 7 & 0.18 & & -45.0 \\
\hline & & 28 & 0.22 & 24.4 & -6.7 \\
\hline & & 56 & 0.23 & 27.4 & 20.7 \\
\hline & \multirow{3}{*}{4} & 7 & 0.21 & & -33.3 \\
\hline & & 28 & 0.23 & 11.7 & -2.2 \\
\hline & & 56 & 0.26 & 21.9 & 34.7 \\
\hline \multirow{9}{*}{ 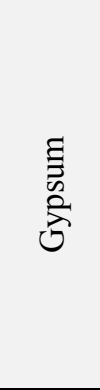 } & \multirow{3}{*}{5} & 7 & 0.18 & & -43.3 \\
\hline & & 28 & 0.23 & 30.4 & -2.2 \\
\hline & & 56 & 0.23 & 30.4 & 23.5 \\
\hline & \multirow{3}{*}{6} & 7 & 0.26 & & -20.0 \\
\hline & & 28 & 0.26 & 0.0 & 6.7 \\
\hline & & 56 & 0.35 & 37.5 & 85.3 \\
\hline & \multirow{3}{*}{7} & 7 & 0.15 & & -53.3 \\
\hline & & 28 & 0.37 & 150.0 & 55.6 \\
\hline & & 56 & 0.46 & 207.1 & 141.4 \\
\hline \multirow{6}{*}{ 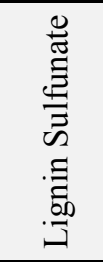 } & \multirow{3}{*}{8} & 7 & 0.18 & & -43.3 \\
\hline & & 28 & 0.19 & 5.9 & -20.0 \\
\hline & & 56 & 0.32 & 76.5 & 68.4 \\
\hline & \multirow{3}{*}{9} & 7 & 0.15 & & -51.7 \\
\hline & & 28 & 0.20 & 31.0 & -15.6 \\
\hline & & 56 & 0.26 & 65.5 & 34.7 \\
\hline \multirow{9}{*}{ 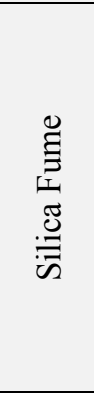 } & \multirow{3}{*}{10} & 7 & 0.32 & & 0.0 \\
\hline & & 28 & 0.32 & 0.0 & 33.3 \\
\hline & & 56 & 0.37 & 16.7 & 96.5 \\
\hline & \multirow{3}{*}{11} & 7 & 0.31 & & -3.3 \\
\hline & & 28 & 0.30 & -3.4 & 24.4 \\
\hline & & 56 & 0.43 & 37.9 & 124.6 \\
\hline & \multirow{3}{*}{12} & 7 & 0.32 & & 0.0 \\
\hline & & 28 & 0.51 & 58.3 & 111.1 \\
\hline & & 56 & 0.38 & 18.3 & 99.3 \\
\hline
\end{tabular}


Table 4: $\quad$ Shear strength of mortar cylinders.

\begin{tabular}{|c|c|c|c|c|}
\hline Mix Name & Mix No. & Days & $\begin{array}{c}\text { Average } \\
\text { shear strength } \\
\left(\mathrm{N} / \mathrm{mm}^{2}\right)\end{array}$ & $\begin{array}{c}\% \text { Change } \\
\text { compared to } \\
\text { control Mix }\end{array}$ \\
\hline Control & 1 & \multirow{12}{*}{7} & 1.14 & \\
\hline \multirow{3}{*}{ White Cement } & 2 & & 1.30 & 14.04 \\
\hline & 3 & & 1.18 & 3.51 \\
\hline & 4 & & 1.19 & 4.39 \\
\hline \multirow{3}{*}{ Gypsum } & 5 & & 1.26 & 10.53 \\
\hline & 6 & & 1.21 & 6.14 \\
\hline & 7 & & 1.49 & 30.7 \\
\hline \multirow{2}{*}{ Lignin Sulfunate } & 8 & & 0.90 & -21.05 \\
\hline & 9 & & 0.82 & -28.07 \\
\hline \multirow{3}{*}{ Silica Fume } & 10 & & 1.27 & 11.40 \\
\hline & 11 & & 1.65 & 44.74 \\
\hline & 12 & & 1.58 & 38.60 \\
\hline Control & 1 & \multirow{12}{*}{28} & 1.55 & \\
\hline \multirow{3}{*}{ White Cement } & 2 & & 1.24 & -20.00 \\
\hline & 3 & & 1.28 & -17.42 \\
\hline & 4 & & 1.38 & -10.97 \\
\hline \multirow{3}{*}{ Gypsum } & 5 & & 1.35 & -12.90 \\
\hline & 6 & & 1.37 & -11.61 \\
\hline & 7 & & 1.90 & 22.58 \\
\hline \multirow{2}{*}{ Lignin Sulfunate } & 8 & & 0.99 & -36.13 \\
\hline & 9 & & 1.27 & -18.06 \\
\hline \multirow{3}{*}{ Silica Fume } & 10 & & 2.15 & 38.71 \\
\hline & 11 & & 2.38 & 53.55 \\
\hline & 12 & & 4.03 & 160.00 \\
\hline Control & 1 & \multirow{12}{*}{56} & 1.32 & \\
\hline \multirow{3}{*}{ White Cement } & 2 & & 1.31 & -0.76 \\
\hline & 3 & & 1.56 & 18.18 \\
\hline & 4 & & 1.39 & 5.30 \\
\hline \multirow{3}{*}{ Gypsum } & 5 & & 1.61 & 21.97 \\
\hline & 6 & & 1.56 & 18.18 \\
\hline & 7 & & 2.26 & 71.21 \\
\hline \multirow{2}{*}{ Lignin Sulfunate } & 8 & & 1.62 & 22.73 \\
\hline & 9 & & 1.52 & 15.15 \\
\hline \multirow{3}{*}{ Silica Fume } & 10 & & 2.39 & 81.06 \\
\hline & 11 & & 3.68 & 178.79 \\
\hline & 12 & & 2.82 & 113.64 \\
\hline
\end{tabular}




\subsection{Shear strength}

Mortar shear specimens of the 12 mixes were tested to determine the maximum resistance of mortar specimens to shear loading. The results of such strength of mortar cylinders are illustrated in Table 4.

Examining the shear strength variation with time of all mixes revealed that there is no clear trend for some of the mixes. Observing the actual failure mode, some samples showed a full plane failure showed while others had a wedge-like plan of failure. For shear strength calculations, only those with full plane failure mode were included in the analysis and presented in Table 4.

\subsection{Wetting and drying cycles}

Wetting and drying cycles were applied to all mixes to simulate a natural environment effect in which samples get affected by water. Samples were subjected to cycles of wetting using normal tap water and sea water. With the use of such test the durability of the different mortar mixes was measured. 6 cycles of wetting and drying were performed. Through the cycles, it was noticed that lime based mortars prepared using gypsum dissolved completely after the second cycle. This took place in both types of water. However, the rest of the mixes stayed intact through all the cycles. The average weight of the absorbed water per cycle as well as the average weight of mortar cubes lost per cycle for all cycles are calculated and displayed in Table 5.

As can be seen from Table 5, all mixes exhibit a decrease in water absorption relative to the control mix except for white cement mixes 3 and 4 and lignin sulfunate mixes. Lignin sulfunate shows an enhancement in the performance over the control mix. Although they absorbed more water, the mixes stayed intact. Thus they maintain their strength in water and do not deteriorate while allowing for wall breathing. The performance of the lignin sulfunate could be tied to its complexing effect. Lignin complexes salts and decreases their effect. In addition, it covers the lime and sand particles decreasing the reaction with salts as discussed earlier. The low absorption of lime based mortars prepared using silica fume is due to the silica fumes pozzolanic action and the very fine particles that fill in the voids and decrease the permeability.

\section{Experimental test results for walls prisms}

Compressive strength of lime stone wall prisms using lime based mortars prepared using lignin sulfunate and white cement exhibit an increase in the compressive strength of wall relative to the control mix of $37.74 \%$ and 18.74 respectively as shown in Table 5. However, the use of silica fume and gypsum resulted in a decrease in the wall compressive strength of $47.04 \%$ and $20.61 \%$ respectively. It was also noticed while performing the test that wall failure starts with mortar being squeezed where debris of mortar start falling, followed by splitting tension of the stone block units, local crushing of stone and finally wall collapse as shown in Fig. 1. 
Table 5: $\quad$ Wetting and drying cycles of mortar cubes.

\begin{tabular}{|c|c|c|c|c|c|c|}
\hline $\begin{array}{l}\text { Water } \\
\text { Used }\end{array}$ & $\begin{array}{l}\text { Mix } \\
\text { Type }\end{array}$ & $\begin{array}{l}\text { Mix } \\
\text { No. }\end{array}$ & $\begin{array}{l}\text { Average } \\
\text { weight of } \\
\text { absorbed } \\
\text { water per } \\
\text { cycle (g) }\end{array}$ & $\begin{array}{l}\text { Average } \\
\text { weight } \\
\text { lost per } \\
\text { cycle (g) }\end{array}$ & $\begin{array}{c}\% \text { change } \\
\text { of water } \\
\text { absorbed } \\
\text { per cycle }\end{array}$ & $\begin{array}{c}\% \text { change } \\
\text { of weight } \\
\text { lost per } \\
\text { cycles }\end{array}$ \\
\hline \multirow{12}{*}{$\begin{array}{l}\text { Tap } \\
\text { Water }\end{array}$} & Control & 1 & 41.79 & 0.29 & 0.00 & 0.00 \\
\hline & \multirow{3}{*}{$\begin{array}{l}\text { White } \\
\text { Cement }\end{array}$} & 2 & 41.62 & 0.22 & -0.40 & -25.29 \\
\hline & & 3 & 45.41 & 0.09 & 8.67 & -67.43 \\
\hline & & 4 & 42.61 & 0.22 & 1.95 & -25.29 \\
\hline & \multirow{3}{*}{ Gypsum } & 5 & 16.44 & 3.33 & -60.65 & 1047.51 \\
\hline & & 6 & 19.52 & 5.77 & -53.28 & 1890.42 \\
\hline & & 7 & 17.66 & 12.31 & -57.74 & 4145.21 \\
\hline & \multirow{2}{*}{$\begin{array}{l}\text { Lignin } \\
\text { Sulfunate }\end{array}$} & 8 & 48.31 & 0.30 & 15.60 & 5.17 \\
\hline & & 9 & 48.88 & 0.22 & 16.96 & -24.14 \\
\hline & \multirow{3}{*}{$\begin{array}{l}\text { Silica } \\
\text { Fume }\end{array}$} & 10 & 40.38 & 0.98 & -3.36 & 239.08 \\
\hline & & 11 & 38.52 & 0.12 & -7.83 & -57.85 \\
\hline & & 12 & 38.74 & 0.22 & -7.30 & -25.29 \\
\hline \multirow{12}{*}{$\begin{array}{l}\text { Sea } \\
\text { Water }\end{array}$} & Control & 1 & 39.99 & 1.43 & 0.00 & 0.00 \\
\hline & \multirow{3}{*}{$\begin{array}{l}\text { White } \\
\text { Cement }\end{array}$} & 2 & 39.44 & 0.11 & -1.38 & -92.62 \\
\hline & & 3 & 41.68 & 0.06 & 4.23 & -95.73 \\
\hline & & 4 & 42.61 & 0.22 & 6.54 & -84.85 \\
\hline & \multirow{3}{*}{ Gypsum } & 5 & 16.87 & 2.49 & -57.81 & 74.05 \\
\hline & & 6 & 17.14 & 1.13 & -57.13 & -20.75 \\
\hline & & 7 & 17.96 & 2.25 & -55.09 & 57.34 \\
\hline & \multirow{2}{*}{$\begin{array}{l}\text { Lignin } \\
\text { Sulfunate }\end{array}$} & 8 & 45.53 & 0.29 & 13.86 & -79.45 \\
\hline & & 9 & 43.70 & 0.26 & 9.28 & -81.90 \\
\hline & \multirow{3}{*}{$\begin{array}{l}\text { Silica } \\
\text { Fume }\end{array}$} & 10 & 37.06 & -0.01 & -7.34 & -100.39 \\
\hline & & 11 & 36.06 & -0.01 & -9.82 & -100.78 \\
\hline & & 12 & 36.66 & -0.03 & -8.32 & -102.33 \\
\hline
\end{tabular}

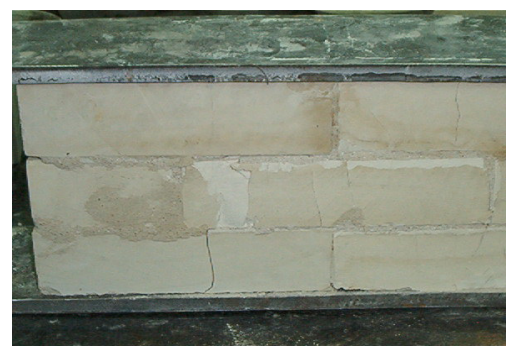

mortar squeezing

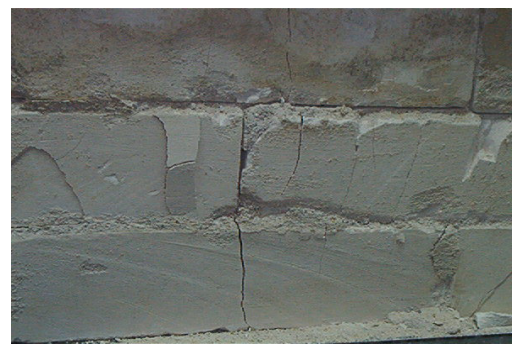

stone tensile cracking and crushing

Figure 1: $\quad$ Typical failure mode of wall prisms using lime mortar. 
Table 6: Compressive carrying capacity of wall prisms.

\begin{tabular}{|c|c|c|c|c|c|}
\hline Mix name & Mix No. & $\begin{array}{l}\text { Maximum } \\
\text { Load }(\mathrm{kN})\end{array}$ & $\begin{array}{l}\text { Average } \\
\text { ultimate } \\
\text { load }(\mathrm{kN})\end{array}$ & $\begin{array}{c}\text { Average } \\
\text { strength } \\
(\mathrm{MPa})\end{array}$ & $\begin{array}{l}\% \text { change } \\
\text { compared } \\
\text { to control }\end{array}$ \\
\hline \multirow{3}{*}{ Control } & 1 & 407.9 & \multirow{3}{*}{408.65} & \multirow{3}{*}{5.45} & \multirow{3}{*}{0.00} \\
\hline & 2 & 402.5 & & & \\
\hline & 3 & 409.4 & & & \\
\hline \multirow{3}{*}{$\begin{array}{c}\text { White } \\
\text { Cement }\end{array}$} & 1 & 473.7 & \multirow{3}{*}{485.25} & \multirow{3}{*}{6.47} & \multirow{3}{*}{18.74} \\
\hline & 2 & 483.1 & & & \\
\hline & 3 & 496.8 & & & \\
\hline \multirow{3}{*}{ Gypsum } & 1 & 459.7 & \multirow{3}{*}{385.25} & \multirow{3}{*}{5.14} & \multirow{3}{*}{-20.61} \\
\hline & 2 & 379.9 & & & \\
\hline & 3 & 310.8 & & & \\
\hline \multirow{3}{*}{$\begin{array}{l}\text { Lignin- } \\
\text { Sulfunate }\end{array}$} & 1 & 517.4 & \multirow{3}{*}{519.1} & \multirow{3}{*}{6.92} & \multirow{3}{*}{34.74} \\
\hline & 2 & 550.5 & & & \\
\hline & 3 & 520.8 & & & \\
\hline \multirow{3}{*}{$\begin{array}{l}\text { Silica } \\
\text { Fume }\end{array}$} & 1 & 245.6 & \multirow{3}{*}{274.9} & \multirow{3}{*}{3.67} & \multirow{3}{*}{-47.04} \\
\hline & 2 & 251.3 & & & \\
\hline & 3 & 304.2 & & & \\
\hline
\end{tabular}

\section{Conclusions}

Within the scope of this study, the following conclusions are presented:

- The best results for compressive, tensile and shear strength were achieved using silica fumes at a percentage of $15 \%$ by weight of lime.

- The use of white cement with lime based mortars results in an increase in the compressive strength for white cement ratio higher than $20 \%$ of lime. As the amount of white cement used increases, the compressive strength of the mortar increases. The increase in compressive strength is then proportional to the added amount of white cement.

- When lime mortars are mixed with white cement or lignin sulfunate, they suffer a loss in tensile strength at 7 and 28 days. Mortars mixed with gypsum or silica fumes showed increase in tensile strength after 28 days.

- Shear strength does not experience the same increase as compressive strength when lime mortars are mixed with white cement, gypsum, lignin sulfunate, or silica fumes. They have a distinct friction shear parameter.

- Lime mortar mixes with lignin sulfunate have enhanced resistance to wetting and drying cycles over all other mixes including the control mix. On the other hand adding white cement, silica fume or gypsum to the lime mortar decreases significantly its resistance to wetting and drying cycles.

- The compression carrying capacity of wall prisms built using lime based mortars with lignin sulfunate and white cement increase over the control mix with the best performance achieved using lignin sulfunate. While using 
silica fume and gypsum in lime based mortar showed a decrease in compressive strength of walls prism.

\section{References}

[1] Davey, Norman, A History of Building Materials. Drake Publishers Ltd., New York, 1971.

[2] Anderson, H. A. et al, Examination of hydraulic lime mortars of medieval churches in Denmark, Proc. of Int. RILEM Workshop "Historic Mortars: Characteristics and Tests, P. Bartos et al. (Ed.) RILEM, 1999.

[3] Bartos P., Historic mortars: characteristics and tests, Proc. of Int. RILEM workshop, Historic Mortars: Characteristics and Tests, P. Bartos et al. (Ed.) RILEM Publication S.A.R.L. 1999.

[4] Binda, L. et al, Experimental study on the mechanical role of thick mortar joints in reproduced byzantine masonry, Proc. of Int. RILEM workshop, Historic Mortars: Characteristics and Tests, P. Bartos et al. (Ed.) RILEM Publication S.A.R.L. 1999.

[5] Hansen, E. F. et al, Effect of aging on lime putty, Proc. of Int. RILEM workshop, Historic Mortars: Characteristics and Tests, P. Bartos et al. (Ed.) RILEM Publication S.A.R.L. 1999.

[6] McKee, Harley J., Introduction to early American masonry, stone, brick, mortar, and plaster. National Trust for Historic Preservation, 1973.

[7] Spewiek, J. P., The history of masonry in America, Proc. of the $7^{\text {th }}$ Canadian Masonry Symposium, Vol 2. McMaster University, Canada. 1995. pp. 663-677.

[8] Zia, P., Ahmad, S. and Leming, M., High-Performance Concretes A Stateof-Art Report (1989-1994), FHWA-RD-97-030, U.S. Department of Transportation, 1997.

[9] Lignin Institute, Lignins-Products with Many Uses, Lignin Institute, winter 1992.

[10] U.S. Roads, Dust: Don't Eat It! Control It, Road management \& Engineering Journal. June 1998. 